\title{
The Effect of Zionist Lobby on America's Foreign Policy towards the Islamic Republic of Iran
}

\author{
Mojtaba Abdollahi ${ }^{1}$ \\ ${ }^{1}$ Department of Political Science, Imam Hossein University, Tehran, Iran \\ Correspondence: Mojtaba Abdollahi, Department of Political Science, Imam Hossein University, Tehran, Iran.
}

Received: July 4, 2016 Accepted: August 10, 2016 Online Published: August 30, 2016

doi:10.5539/jpl.v9n7p262 URL: http://dx.doi.org/10.5539/jpl.v9n7p262

\begin{abstract}
Undoubtedly, no country as America is the host and influenced of pressure groups, and because of the existence of the interests and valuation system in America, this issue has made decision making in foreign policy of this country difficult. Among pressure groups in America, Zionist lobbies seem to have the most influence in America's foreign policy. Based on this, it can be approximately said that America and Israel have had special ties after the World War II and AIPAC Group has always guaranteed the continuation of this relationship. A set of factors play role in forming foreign policy of each country internally, nationally and internationally that the outcome of these factors' action and reactions will is presented as the outcome and "foreign policy". The United Sates of America's foreign policy is also the same process, based on this according to the international relationships ideas which of the important levels in analyzing foreign policy of the United States of America is internal level whose one of its components is investigating the role of pressure groups in forming the foreign policy of this country, practically the activity of any groups isn't as prominent and highlighted as Zionist lobby in this subject.

Therefore the author of this research is sought to investigate the effect of different shapes of Zionist lobby and the position and performance of this regime in America's foreign policy towards Iran, hence the arrow of lobbying activities in the area of Iran is also evaluated; consequently in the process of the research, stating that influential element in the system of decision making in The United States of America about the role of stakeholder groups with a focus on Zionist lobby and the unwavering support of the United States from this lobby is undeniable.
\end{abstract}

Keywords: AIPAC, the lobbying, foreign policy

\section{Introduction}

A set of factors play role in forming foreign policy of each country internally, nationally and internationally that the outcome of these factors' action and reactions will is presented as the outcome and "foreign policy". The foreign policy of the United States is also the outcome of the same process and is derived from the interaction of three mentioned levels. Based on the ideas of international relationships, one of important levels in analyzing the foreign policy of the United States is the internal one which investigates the role of democratic and republican, leaders and prominent politicians, congress, public opinion, big business owners, think tanks and pressure groups in forming foreign policy. Meanwhile when America's foreign policy in Middle East is discussed, the subject of Zionist lobby is more prominent and highlighted among the other factors. Despite the information above, in the studies of international relationships, the case which has drawn the author's attention and basically the author is going to investigate it is what factors caused the Zionist regime to be reliance of United States of America in its international interactions and if we draw this conclusion that there is such this reliance, what the factors of powering Israel's lobby packs about United States' interactions are.

The main question of the researcher in this paper will be investigating the effect of different shapes of Zionist lobby and the position and performance of this regime in the foreign policy of America towards Iran.

Since the process of interactions and exchanges of United Sates of America is based on organized formations of this regime in global arena and particularly the Middle East because of common interests with Israel, and considering the investigation of the process and layout of mentioned regime lobbying structure, the necessity of evaluating how Israel's lobbying has been formed and powered and the influence of lobbyists in the foreign 
policy of United States of America and its effect on Iran's international presence hasn't been affectless, therefore investigating and data mining the process of these fluctuations and America being affected in its foreign policy towards Iran is considered as the core problem of this research.

According to the accomplished researches, there have been suitable scientific researches about the effect of Zionist lobbying on the foreign policy of the United States of America up to now, but the indicator which the current study is going to investigate is the effects of Israel regime lobbying on the foreign policy of the United States of America towards Iran that in fact investigates America affectability of mentioned lobby in details.

For example, the book "Jewish lobby and America's foreign policy (emphasizing on picturing of the Jewish lobby against Iran)" written by Dr. Asghar Keyvan Hosseini can be mentioned in Persian compilations that investigates the reason of powering Israel defender lobby in America and is sought to analyze this process (powering Israel defender lobby) through decision making theory. Considering the grounds and factors that he has stated, he believes that this lobby has been able to increase its power during the time in cumulative form, although it has been faced with some challenges in this way such as being ignored by some of America's presidents (that of course was sectional), some challenges have also been created within Jewish community (However trimmed) for supporting Israel. But this lobby generally seems to remain as one of the most important influential and effective groups on the data of America's foreign policy. In the area of English also among published books, "The Israeli lobby and America's foreign policy" written by two authors Stephen M,Walt and John Jay. Mearsheimer can be mentioned that was published with translation of Reza Montazami and Mehran Nasr by Khorsandi publication. After publication, this book was discussed in intellectual circles, research centers and among the known people of West intelligentsia and provoked many challenges. This work was the beginning point for writing books and articles and discussion about the dominance of Israel's lobby network on America and Europe and after its publication, Zionist lobby entered the prevailing discourse and political literature of West.

Beside the researches which have been accomplished about the effects of Zionist lobbying on foreign policy of America against Islamic Republic of Iran, the author is sought to specifically follow the effects of these lobbies on foreign policy of America against Islamic Republic of Iran and this research is innovated hence there hasn't been any researches with the same subject about Iran up to now so the author has interpreted and described the effects of mentioned lobby on foreign policy of America against Islamic Republic of Iran through the documentary approach.

This research is done through descriptive and interpretational and documentary methods.

So it is tried to investigate the role of Zionist lobby on foreign policy of America against Iran descriptively and interpretational as independent variable and America's movement toward the policy of harnessing the Islamic Republic of Iran as dependent variable.

These days, identifying pressure groups is one of the important discussions in forming public policy. These groups are trying to affect policy makings and decision makings in different ways to achieve their interests. The history of relevant studies to stakeholders groups refers to the beginning of $20^{\text {th }}$ century. Although this phenomenon isn't new and even is older than parties but the main concept of pressure group, which is called stakeholder group either, was first drawn in America and was studied for the effects of organizations and private forums on government. (Duverger, 1993, 535) Although it can be claimed that most of political decisions are affected by the activities of pressure groups but studying and investigating these groups haven't been considered as much as having significant roles in political process. Of course in some pluralistic societies because of the abundance and diversity of these groups in the field of sociology, there aren't significant studies about them. On the contrary traditional and total systems because of their political structure have closed the way for forming, growing and activities of these groups and limited their territory. On the other hand one of the factors which make the relevant studies to stakeholders' groups and inhibit from achieving a certain result is the complexity and hide of their programs and behavior; this will reach to its pick particularly in developing countries. (Naghibzadeh, 1989, 13 and 15) The importance of this subject is so much that some of political theorists believe that today, political regimes shouldn't be studied based on parties systems but the role and performance of pressure and stakeholder groups should be studied. (Kordenaeig, 2006, 67)

\section{Foreign Policy of America}

From history's point of view, America's policy has been always fluctuated between idealism and realism.

\footnotetext{
${ }^{1}$ Asghar Keyvan Hosseini, “Jewish lobby and America's foreign policy (emphasizing on picturing of the Jewish lobby against Iran), the publications of Motaleat Andishesazan noor institute, fall 2009
} 
The core of foreign policy of America during previous half-century has been creating and maintaining a stable international order. This order has been necessary for dissemination and institutionalization of political and economic patterns of America that has been followed whether during Cold War or after The Soviet collapse continuously.

Foreign policy of America has been accompanied with special features that are going to be mentioned as follows.

The first point is related to how the relationship is between "American democracies" and "foreign decision making system", in another word, the thing which turns the foreign decision making of democratic communities to a complicated and full of wonders is the presence and effectiveness in different world. In one world we are facing some components such as international policy, the balance of power, wars and alliances and mercenary and brutal use of diplomacy entry in order to affecting others' behaviors and in another world we can see internal politics, interest groups, political parties and political classes with opposite interests and goals. This situation regarding America has been accompanied with the role of other component which is called "Consensus in times of crisis and Diversity in the period of peace".

The second point includes informal methods of decision making in the level of foreign policy of America. In this field the concept of "The circle decision-making" has been common and considerable issue based on that, exploiting specific bargaining channels including a limit spectrum of consultant will get higher priority compared to formal institutions such as National Security Council.

The third point refers to cultural and valuable components effective on foreign policy of America; in another word the interaction pattern between "Inheritance environment" which was revealed in the method of getting relationship of initial immigrants with pure, expanded and rich land of America, gradually brought particular consequences economically, politically and socially specially religiously. (Hosseini, 2009, 27-30)

\section{Pressure Groups and Foreign Policy of America}

Lobby or influential groups in the United States are those groups that in order to realizing their goals and interests, using political and legal capacities and structure of this country, are looking for affecting its trend and political, internal or foreign direction.

In recent years, by increasing the parliament capacity of the United Sates, the power of mentioned groups whose main activity centers are in congress and senate has been increased. In this framework the first function of lobby is providing information, the lobbies provide required information of congress or senate members through the forms below:

1) Proposing some information about plans and bills' future and prospects for approving or rejecting them

2) Research and investigation about the election consequences, rejecting or supporting discussed bills and proposing to the senators

3) Informing about environmental, political, economic, social and cultural consequences, approving or rejecting the mentioned bills due to the senators' direction

The second function of influential groups, pressure groups, is indirect effectiveness on legal, legislating and execution decision making. (Laforki, 2008, 19-20)

\section{The Roots of the Zionist Lobby}

Zionist lobby in America is reputed to Israel lobby and Zionists try so hard to name it as America's Jewish lobby rather than Israel lobby, according to Stephen Walt and John Mearsheimer, Israel lobby means the influential groups and organizations that put the way of forming foreign policy of America and perceiving national interests resulting from that into challenge and always try to persuade the legislators, positions and the members of government to guarantee their suggestions and ideas due to support Israel interests. (Mearsheimer, 2013, 177)

Major and fundamental Israeli lobby in America is formed by American Jewish. These are people who spend their capital and time deeply on organizing foreign policy of America to assure the alignments of foreign policy of America with Israel interests.

\section{The Structure of Zionist Lobby}

Zionist lobby in America is receiving interest and benefit in two modes, formal and informal mode. In formal mode, we can see organized groups and formations which are trying to affect congress or government and lead the trend of governmental and parliament interactions of America due to Israel interests such as (America- Israel Public Affairs Committee) known as AIPAC that of course these groups formally have some powers in the field of administration and law that facilitate and speed the trend of activities such as Christian Right organizations, 
Southern whites, conservatives and neo-conservatives. Both two parties of America should be also considered as non-Jewish factor but among the official Zionist lobby and its constructive and facilitator components. On the contrary, there is informal mode that groups don't enter the arena directly but sometimes they are affecting the equations of America's foreign policy through collecting information and persuading their members for participating in elections and recent political subjects so they don't have a wide span of activity like those groups such as AIPAC.

Jews in America are very active in America politically, socially and even economically and ironically this social range in America have the highest voting rate among ethnic groups. Although this ethnicity forms 2 to 3 percent of The United State of America but almost 94 percent of them live in America's thirteen key states. (Leforkey 2008, 104)

\section{Israel Influence Tools}

1) Influence in congress and senate

An effective key pole in Zionist lobby is influencing in the components of America's congress because Israel is usually safe from criticism in America's congress that the main reason of this safety is that the essence of congress belongs to this principle that it doesn't make difference in subjects that have been created among representatives of intellectual consensus and even stabilization of this unchangeable principle about Israel is derived from the key members of congress that mostly are the members of Zionist regime defender.

\section{2) Influence in white house}

The influence of voters in presidential election is very important therefore Zionist lobby like congress election is powerful to apply its ideas. After selecting the president, key organizations of lobby in United States try through their lobbying not to let the people and groups opposed to Israel to be selected for governmental positions and important jobs. For example Jimmy Carter wanted to select George Ball as his government's foreign minister and he also knew that this person is the critic of Israel so Israel lobby disagreed selecting him. Based on this and because of such this spirit, the politicians are encouraged to support Israel overtly and on the other hand the opponents of this regime don't have enough opportunity to enter the political arena of this country. (Ghavidel, 2001, 227)

In fact lobbies and stakeholder groups, whether influencing in the congress of the United States through direct ways or indirect ways, considerably have influence in the executives of law. Most of America's presidents are less defeated by congress agents and sometimes make some decisions about disagreeing with Israel lobby in congress. Of course with the connivance of some cases such as the possibility of reducing the theory of strategic value of Israel or disagreeing or continuing occupying Palestinian lands, there aren't usually serious opposition and certain operations on the behalf of America's presidents toward the lobby expectations, generally the presence of Jewish in America's election is because of the power of influence of this social range in executive branches if America's governmental system.

\section{3) Controlling the media}

One of the most important tasks of Israel lobby for positivizing the activities of Israel regime is controlling and dominating the media that reports and shows of this regime are provided and then broadcast in society through the best media and most popular programs to the extent that providing news and reports in each network should be due to positive explanation of this regime's performance. For example if a serious and explicit criticism is discussed in one of the media towards this regime or its lobby, all media cover it in a groups so that Zionists' interests be safe which this trend is certainly isn't aligned with a democrat society. (Ghavidel, 2001, 237)

4) Think tanks

Zionist's lobby has been always interested in intellectual communities that have an important role in forming the public discussions and practical policies. Israel's lobby has a prominent group of consultants and intellectual cores that are able to lead public thoughts in accordance with Israel's interests. Aside from relying on high governmental positions of America that always analyze the approaches of Middle East to Israel, this lobby has a group of intellectual consultants that by employing them, reflect the ideas and votes of Jewish in the society because this selected intellectual core is interacting with America's media and through this, they clear the people's mind toward the interests and goals of Israel.

\section{5) Monitoring academic centers}

The other case that Israel's lobby has influence in it due to its interests is academic and educational center of the United States but because of principle and basis of thought and speech freedom in academic centers of the 
United States, this lobby has big problems about these tools. The universities in America has been attracted non-American students and professors from different parts of the world for more than 30 years to the extent that these academic centers play their role as international institutions and ironically criticizing Jewish lobby and Israel regime are more discussed by non-native students and professors of America.

\section{America's Supports of the Zionists' Lobby}

Because of having geopolitical position of Jewish community and Zionist in the United States, Israel is considered as a strategic advantage and the evidences show that today Israel is one of the biggest recipients of America's foreign helps that of course this trend has been continued since 1976.

From 1949 to 1965 the average helps of America to Israel was annually more than 63 million dollars that more than 95 percent of that was the economic and nutrition helps. The program of America's helps to Israel continued more than 102 million annually. (Azadi, 2004, 230)

It is noticeable that supporting Israel by America has been always justified with this issue that because Israel is considered as supporter of democracy in the region hence it should be supported while all over the world, there are other democrat-basis governments that need the contributions of America but the United States doesn't pay any little attention to them.

Generally it can be said that in the United States there are four main sources of financial, ideological and political supports for helping dependent economy of Israel:

1) Wealthy Jewish supporters and powerful and coherent media for fundraising

2) The government of the United States, congress and president

3) Mass Media specially New York times, Hollywood and important channels of TV

4) The heads of trade unions and pension fund managers

\section{Israel and AIPAC's Positions against Iran}

it would definitely be said that if all the policies of the United States toward Iran isn't the result of Zionists' thoughts, a vast part of America's decisions is affected by Zionists approaches and its relevant organizations because through the authorities in Iran, these organizations intervene not only in Iran but also in all global and internal problems of the United States and among Zionist organizations, AIPAC has been able to use all possible opportunities due to stabilization and applying its attitudes in congress and senate and other decision making institutions in America more than others because of the closeness to power centers of America that its main headquartered is in White House.

Therefore the way that America considers Iran is affected by Zionists approach to the great extent because with an implicit observation in resolution of Congress in America against Iran, we can draw the conclusion that these resolutions are approved by AIPAC and Zionists or at least by their certain support.

Meanwhile considering macro foreign policy of Islamic Republic of Iran based on the defense of Palestinian positions and denial of political legitimacy of deployed government in Tel Aviv which with challenge between Iran and Israel have led to divergence and opposition of America toward Iran, the relationships between Iran and America should be considerably analyzed under the role of Israel.

Israel and its agents have followed neutrality policy during the years 1984 to 1988 but after that Israelis considered Iran as a tri threat sources. Firstly militarily, Iran's victory was considered as the worst threat for Israel and secondly ideologically, Islamic revolution operated as a pattern at the service of Islamic fundamentalism in Lebanon and among the Palestinians and thirdly Iran was considered by Israelis as the source of issuing terrorism.

Due to this one of the important, powerful and effective tools in America's governance system is Zionist regime lobby which acts as two modes of formal and informal lobby. Formal lobby includes organizations and organized Jewish and Zionist groups that apply pressure in decision making of America's legislation and America's governing apparatus directly and the most important ones is American-Israelis public affairs committee (AIPAC) and global congress of Jewish. Informal lobby also includes wide participation of Jewish in election and the presence of Jewish in sensitive posts of America.

Iran id a core subject in all annual meeting of AIPAC that of the most important ones is "AIPAC National Summit" that is annually held in October and "AIPAC policy conference" which is held in March. So since Iran is the key subject of these meetings, investigating relevant contents to Iran in these meetings is very functional and important. More noteworthy issue in these meetings is getting threat approach and investigating the 
influence in foreign systems relevant to Iran in The United States of America which leads to the problems such as Iran sanction, accusing it of terrorist activities and weakening nuclear program of Islamic Republic of Iran.

AIPAC hostile policies and new subjects are immediately used against Iran as a weapon on the behalf of AIPAC policy makers, undoubtedly with the history that AIPAC has had in creating tense atmosphere against Iran through accusing Iran of supporting terrorism among countries, the strategic importance of this tactic used by Israel regime can be perceived and following that the reason of the Iran issue being central in AIPAC meetings gets clearer.

Iran sanction is another most important subject of AIPAC sessions. AIPAC committee in mid-1990 has tried to discuss the idea of Iran sanction that was turned into Iran sanction strategy inside Jewish lobbies with different reasons as the priority of America's foreign policy toward Iran and approve it as a law that the idea of blocking Iran's assets is also one of these sanctions. (Tabatabaei 2006, p 36)

Sanction option has been always on the table for Zionists against Iran and they tried a lot to make it operational. Based on this in the field of sanctions, by Zionist lobby, different plans such as Mutual inhibition initiatives or the D'Amato Act Aylsa ${ }^{2}$ and ... in America due to applying pressure on Iran have been approved and administered.

This point should be mentioned that a process whose end was approving and administrating sanction law against Iran by the structure of foreign policy of America, started where the idea of sanction was discussed in brokerage that is Jewish lobby. Planning the idea of sanction in brokerage was the beginning point of a process that should be designed by brokerage to convert the plan to a strategy for action and then this strategy was discussed as a part of America's national interest considering the features of Jewish lobby brokerage to be approved and administered as following. (Tabatabaei 2006, p 38)

Considering the policies of America against Islamic Republic of Iran, many American and Israelis sources consider the role of AIPAC in the interaction of these two countries very important and influential. Since Israel has announced Iran as the biggest enemy of its own, this committee has made a lot of attempts in order to worsen the action of White House against Iran during past years considering the emphasis of America and Israel on the necessity of putting an end to Iran's nuclear activities.

The effect of Zionist lobby in changing the positions of the White House warns also another point and that is the power of this group in directing foreign policy of America and advancing it in the desired direction of Zionist regime.

Undoubtedly the fear of Iran being patterned and expanding the thoughts of religious government of this country is one of the considerable issues for Israel and following that America that is considered as threat for national security strategy of both two countries. it seems that despite Zionist lobby through proposing the plans such as overthrowing Iran or military attack to this country plays a main and effective role in agitation and propaganda for making mentioned plans operational in United States but it was recognized among the governors of America that "the function of attacking Iran's nuclear facilities may have reverse result and create catastrophic consequences in the region". (Mearsheimer 2013, 446)

\section{Conclusion}

Considering central position of Zionist lobby and its influential tools that is AIPAC in America, political, security and even economic actions of the United States in the world specially Middle East and particularly Iran, are managed by Zionist regime and since the drawn network in internal policy of America is derived from Zionist approaches and ideas, exterior incidence of this approach isn't different from its interior content and hegemonic policy of America cannot be controlled with influential tools such as AIPAC and in fact the system of America's decision making is saturated because of Zionist lobby stakeholder groups' role and supremacy thought of this ethnicity and it seems that deep effects of picturing of beneficiary groups especially AIPAC is undeniable in dominant interactions of America's international relationship towards the world since a wide part of ongoing uncertainty in the interaction between Iran and America is mainly the product of presence and effectiveness of tension variable such as Israel and its lobby in decision making structures in the United States. Of course it is obvious that only Israel isn't the ravages factor of relations between Iran and America but the most effective assumption in the indicators of America foreign policy is this regime and its wandering lobbies in the United States that manage the policies of America towards the countries of this area specially Iran due to protecting its interests in the Middle East and since Israel is the main actor of America's plans in Middle East and owning

${ }^{2}$ Iran LYBIA SANCTION ACT 
common interests and identity joints with this country, America also designs its programs in Israel's puzzle.

Based on this almost all stated and actions positions of United States towards Iran during the recent 35 years have been in accordance with Zionists' interests to the extent that without considering Israel's interests, America will never be able to achieve its interests in Middle East.

After the revolution victory and considering the lack of common identity and attitudes between the people and authorities of Iran and Israel, the framework collapsed and there wasn't unity triangle between Iran, America and Israel anymore. According to the author basically lack of agreement in political definitions such as security and so on in Iran and Israel's point of view will have threat performance tools toward each other for example when security for Israel is merely lack of threat against government and for Iran it is defined as the existence of internal and external threats against values and beliefs and the institutions of society, certainly for realizing the dominant literature on these definitions will be the performance of these systems.

It was tried in this research to evaluate the effect of lobbies and main arms of Israel in the United States towards Iran and proving this subject had been the main basis of the researcher that in most of America's political decisions particularly in the field of foreign policy toward Iran have been affected by the attitudes and effects of pressure groups such as AIPAC.

Based on what is said, among political units of the world, no country as Israel has had influence in America and Israelis exactly have tried to suppress Iran in any way by American and non-American tools and their Zionist policies and they haven't discarded any hostile actions to collapse this system.

Therefore it seems that different variables in foreign policy of America are trying to get their desired output through entering their desired input in the process of foreign policy of this country. Here where the conflict in the strategic relations between Iran and America are more and non-convergence and consensus than before especially that the big effects of AIPAC groups in interactional circle of America are very conflicting and unconstructive.

Therefore if we are looking for achieving Islamic Revolution's strategic goals nationally and internationally we have to enter new considerations regarding Geneva Agreement and Iran's nuclear activities and following that, negotiations with the United States after thirty years leaving of interaction between the two countries inside local and foreign policies decision making effectively because the beliefs and ideological values of IRI backed by the principles of foreign policy according to supreme leader Khamenei are due to dignity, wisdom and expediency of the system that the general policies of Iran's international relations are sustainable and can be administered on this principle.

\section{References}

Aghamohammadi Ebrahim. (2005). Net foreign policy decision-making in America focused on the Middle East case. Journal of Ettelaat, (18).

Ahmadi Lafouraki Behzad. (2008). The lobby and lobbyists in America. Tehran, International studies and research institute of contemporary Abrar Tehran.

Ben Meyer, A. (2012). Israel reactions on nuclear Iran. translated by Karami Navehkash Mohsen, Journal of regional studies (Israel survey - America survey), Year of 13, No. 3

Charles, W. (2009). America's foreign policy, patterns and trends. translated by Dastmalchi Asghar, Tehran, Institute for political and international studies.

Ghavidel Mahdi. (2002). book introduction: Religious aspect of America's foreign policy In the Arab-Israeli conflict: review of American Christian Fundamentalist movement. Journal of regional studies (Israel survey - America survey), (13).

Hosseini Seyed Asghar Keyvan. (2010). Redefining the role of defender of the Jewish and Zionist lobby in the America society and politics. Journal of political and international approaches, (21).

Hosseini Seyed Asghar Keyvan. (2010). Transformation process in the role playing pattern of Jewish minority in America, from minority immigrant to influential lobbying. Journal of strategic studies of Islamic world, $11(42)$.

Javan Shahraki Maryam. (2008). Theoretical foundations of America's foreign policy after September 11. Journal of strategic research institute, (11).

Kord Naeij Asadollah. (2006). The role of pressure groups in shaping public policy. Management culture, 4(12).

Maurice Duverger. (1993). Political Sociology. translated by Ghazi Abolfazl, Tehran, Tehran University. 
Mearsheimer, J. J., \& Walt, S. M. (2005). The Israeli lobby and America's foreign policy, translated by Saeed Kolahi Khiabani Hassan and Asgarian Hossein. Journal of Regional Studies of the Islamic world, (24).

Mearsheimer, J. J., \& Walt, S. M. (2013). translated by Nourizadeh N. "The Israeli lobby and America's foreign policy", Tehran, Mitra publications.

Naghibzadeh Ahmad. (1989). Hidden pests of democratic system. Economic and political information, 4(32).

Naghibzadeh Ahmad. (2008). Introduction to Political Sociology. Tehran, S.A.M.T.

Tabatabaei Seyed Ali. (2006). Jewish lobby of America - Agents of Iran's sanctions. Foreign Policy Journal, (1).

\section{Copyrights}

Copyright for this article is retained by the author(s), with first publication rights granted to the journal.

This is an open-access article distributed under the terms and conditions of the Creative Commons Attribution license (http://creativecommons.org/licenses/by/4.0/). 